\title{
INTRODUCTION TO BORDERS AND LIFE-STORIES
}

\author{
Tuulikki Kurki, Kirsi Laurén
}

Borders came into global focus during the last decades of the twentieth century. The reason for this was the large-scale geographical, political, and societal changes that took place in Europe, for example, the disintegration of the Soviet Union, the fall of the Berlin Wall, the formation of the European Union, and the gathering momentum of global migration movements. These large-scale changes permanently altered the characteristics and significance of national borders in Europe. Instead of being boundaries of strict separation, borders became flexible gateways and pronounced areas of interaction and negotiation. Furthermore, the large-scale changes which were being experienced had a strong impact on the lives of individuals in various borderlands. They altered the way that individuals and groups of people, whose lives were affected by the presence of borders, defined their identities. Since the establishment of the modern nation states, the rhetoric that constructs national unity and the socalled national culture has confined identities and cultures to specific, clearly bounded geographical areas (Malkki 1992). From this point of view, emigrants and refugees appeared simply as dislocated people and as 'the others' to the dominating national cultures and societies (Hammar-Suutari 2009; Ronkainen 2009; Davydova 2009). Today, due to global migration and the opening of national borders, the need to construct identities on different bases has become necessary. New identities are not necessarily confined to a place, region, or ethnicity. Instead, they are constructed in relation to borders and movements across them (Alvarez 1995; Paasi 2002).

Since the beginning of the so-called topic of border studies in the $1980 \mathrm{~s}$, the focus of research has mainly concentrated on national borders, cross-border cooperation and border practices. In these approaches where geography, history and social sciences have dominated research, the border has been understood mostly as a tangible and political entity. Cultural borders, on the other hand, have featured in humanities research since the late 19th century. One of the 
earliest noted researchers to discuss borders from an anthropological point of view was the German ethnologist and geographer Friedrich Ratzel (1844-1904). His approach has been labelled as anthropological geography (Anthropogeographie) and it forms the beginnings of modern political and human geography (Cahnman 1943; Danielsson 2009: 1-2). ${ }^{1}$ During the 20th century, anthropology, ethnology, linguistic and cultural studies, for example, have focused on the borders between cultures and languages, and on social borders between the sexes, age groups, and class (Van Gennep 1909; Douglas 1966; Turner 1977). Furthermore, the symbolic bordering processes and construction of the cultural 'other' have been the stimulus for essential questions in cultural anthropology since the establishment of the academic discipline in the late 19th century.

Within Europe, borders received renewed interest in cultural research due to the changes in geography and the geopolitical balance (Schimanski \& Wolfe 2007). However, in Anglo-American anthropology and geography, the USAMexico border had already become the focus of attention in the 1950s and 1960s (see Anzaldúa 1987; Hicks 1991; Alvarez 1995; Sadowski-Smith 2008). During the past decades in Finland, borders have been explored within landscape studies, from the point of view of cultural representations. Case studies have been conducted that focus on Finnish-Russian Karelia (the area divided by the Finnish-Russian national border) and from the viewpoints of ethnicity and locality in the border area (Häyrynen 2006; Fingerroos 2004; Löytty 2005; Davydova 2009; Suutari \& Chikalov 2010; Hakamies 2012). During the past ten years, new trends in studying borders have emerged. In literature research and cultural studies, and for example, a stress on the aesthetic, literary and artistic aspects of borders can be seen (Schimanski \& Wolfe 2007; SadowskiSmith 2008; Nyman 2009; Järviluoma-Mäkelä et al. 2012).

In contemporary cultural research, the border is often examined as a space and place where various individual and collective (e.g. cultural and political) interests and significations confront each other (Knuuttila et al. 2006; Silberman et al. 2012). Usually, the voices of the groups in power and their expressed meanings of the borders dominate public discussion. However, borders that are experienced and signified by individuals do not necessarily follow these politically defined borders or the significations of borders that are collectively or commonly shared. In everyday life, borders are formed on the micro-level by social interaction, and through individual experiences and narratives. Nevertheless, political and ideological discourses influence the way the borders are accounted for in individual oral or written narratives.

The theme issue Borders and Life-Stories focuses on geographic, cultural and micro-level borders which are examined through written life-stories and narratives. The micro-level perspectives used in these articles make visible 
symbolic and metaphoric borders, which often remain completely unrecognised in the wider macro-perspectives. There are two reasons why these remain unrecognised: The first is that outsiders do not recognise them, because at a microlevel, symbolic and metaphoric borders only become recognisable in everyday interaction. The second reason is that symbolic and metaphoric borders are so self-evident to insiders that they often remain unexplicated, even though such borders influence everyday interaction. Due to the characteristics of symbolic micro-level borders, they must be studied by means of methods, materials and viewpoints different than those used to study political and institutional borders. Everyday life and experience-based narratives concerning borders and borderlands have been a special focus of attention in anthropology, folklore studies, and literature research, as well as the marginalised voices of women and various minorities on various national, cultural and social borderlands. However, these viewpoints have recently become the focus of attention in political geography, human geography, and sociology (e.g. Eskelinen et al. 1999; Pöllänen 2007; Silberman et al. 2012).

The articles of the theme issue Borders and Life-Stories examine published and unpublished memoirs and life-stories, as well as poetry, in which national borders, borderlands and crossing borders are central themes. The life-stories and memoirs are individual accounts, yet they reflect the collective, culturally shared narratives and meanings of borders that are maintained in literature, media, art and politics. Therefore, the analysed texts open viewpoints to larger cultural and collective narratives about borders and make visible their multilayered character.

The articles stress two themes in the analysed texts: The first is the narrative construction of the narrator's identity in relation to the national border, and in relation to 'we' and 'other' on the different sides of the Finnish-Russian, Estonian-Russian, or the Finnish-Swedish national borders. The identity formation process in relation to the national border is often emotional and traumatic. In these cases, the border appears as a dividing line or a boundary that has a permanent influence on an individual's life. For example, the border can violently separate the narrator from his or her roots, home, and family members, or society or the 'other' people across the border are experienced as a threat. One of the strongest motives to write a life-story, memoir or poem may be the narrator's need to process his or her emotions and trauma, and to form a coherent life-story that has trajectories from the past towards the future (Aarelaid-Tart 2006). The second theme is the construction of various symbolic and metaphoric borders contained within the narratives. The time, place, and space of the narration influence how the narrators make the border understandable and meaningful to themselves. Therefore, the life-stories, memoirs, and 
poems that are covered, reveal the flexible and unstable characteristics and meanings of borders to the narrator.

The theme issue consists of four articles. Tiiu Jaago examines life-stories of an Estonian woman who was born in 1918. The woman wrote four separate life-stories in 1996-2004: three while living in Estonia and one while living in Russia. The narratives describe the narrator's life with her closest circle of acquaintances, and also whilst being alone (both when free and imprisoned), in her homeland and abroad. Jaago studies these life-stories using Juri Lotman's theoretical framework of the cultural border and focuses on the following questions: Where are cultural borders located? Are such borders perceivable? Who can define the borders? Jaago's analysis of the life-stories reveals the ambiguous and flexible characteristics of borders. Furthermore, Jaago's article emphasises that the understanding of the cultural 'other' is always subjective, contextually determined, and strongly bound with the narrator's life story.

Kirsi Laurén's article studies elderly Finnish people's attitudes towards the Finnish-Russian national border and life in the national borderland. The focus of the analysis is on the subjects' written memories and especially on the narrators' emotions and the fear that they expresses in the narrative. One reason for the centrality of emotions and fear in the narratives is that World War II (which caused significant geographical and cultural changes in the Finnish-Russian national borderland) still appears as a significant time period in the narrators' memories. The analysis reveals that emotions that stem from war memories have a long-term influence on the narrators' concepts of the [Russian] border and [Russian] people. Everyday life, on the other hand, is characterised through the concepts of remoteness and wilderness within the narratives and the narratives' concerns over the fear of predators, for example, crystallises the idea of the remoteness of the borderland areas in relation to the populated centres.

Tuulikki Kurki's article focuses on Finnish writer Taisto Huuskonen and his novel The Child of Finland (Laps' Suomen, 1979). The biographical novel describes Huuskonen's illegal defection to the Soviet Union in 1949, his life in the Soviet Union and his return to Finland in 1976. The article claims that crossing the national border had a crucial impact on Huuskonen's life-story and identity. The reason for this is that crossing the border in one direction or the other forced Huuskonen to redefine his identity, belonging and loyalty towards various ideologies and nations. The crossing of the national border and its consequences were also a traumatic experience, which had a strong influence on how Huuskonen constructed his narrative 'I' in relation to 'us' and 'others' on the different sides of the national border. The article interprets Huuskonen's novel in the context of trauma literature. The writing in which the trauma was concerned was caused by a voluntary or involuntary movement across the 
Finnish-Russian border, which was politically problematic in Finland until the late 20th century. Nevertheless, the number of trauma literature narratives on this topic has increased in Finland and also globally as a genre since the last decades of the 20th century. The context of contemporary trauma literature opens Huuskonen's novel for discovering meaningful ways of reading in the 21st century.

Anne Heith's article examines how the experiences of internal colonialism may be expressed in literary writing through the analysis of Bengt Pohjanen's poem Ragheads (Rättipäät, 1996). Bengt Pohjanen is a writer using Meänkieli (Tornedalian Finnish) in the Tornedalian valley in the Finnish-Swedish national borderland. In the analysis, Heith focuses on the tension expressed in the poem, which is caused by the homogenising modernity in a Swedish nation-building context, and the particular situation of the Tornedalian Finnish minority in northern Sweden. The article proposes that the poem represents a re-mapping of 'the national' and 'the international' as commonalities are established between the Swedish national minority of the Tornedalians and migrants in European metropolitan centres.

In addition to the articles, an interview of Professor Stephen Wolfe is included in the theme issue. Stephen Wolfe has a prominent role in the cultural research on borders: in addition to several publications on the border theme, he is the co-organiser of the Border Poetics research group at the University of Troms $\varnothing$. In the interview (conducted in December 2011), Wolfe introduces his own research in border studies as well as some topical issues of cultural research that focus on borders.

To complement the articles on borders and life-stories, two review articles examining films and borders are included in the theme issue. The first, written by Holger Pötzsch, examines Knut Erik Jensens' documentary film Stella Polaris (1993), which is a constellation of memory fragments pertaining to life in a northern Norwegian fishing village over a period of 50 years. Pötzsch's analysis focuses on various ideas of liminality within the film. A second review, written by Saija Kaskinen, analyses Lauri Törhönen's film Border 1918 (Raja 1918, 2006). The film focuses on the aftermath of the 1918 War in Finland and establishing of the national border between Finland and Russia. The analysis discusses the border as an entity that determines the development of the characters in the film.

The theme issue also includes Tiina Suopajärvi's review of a methodologically centred article compilation Along Textual Borders. Multidisciplinary Perspectives on Written Materials [Tekstien rajoilla. Monitieteisiä näkökulmia kirjoitettuihin aineistoihin] (SKS, Helsinki) edited by Sami Lakomäki, Pauliina Latvala and Kirsi Laurén. The compilation (published in 2011) introduces fresh 
methodological approaches in text analysis, written by scholars in cultural and folklore studies, anthropology, literature studies, history, and social sciences.

As editors, we are most grateful to the writers of the theme issue: Tiiu Jaago, Anne Heith, Holger Pötzsch, Saija Kaskinen, and Tiina Suopajärvi. We are very grateful to Stephen Wolfe for the extensive interview, which he kindly provided to us in writing. We are most grateful to the refereers of this theme issue for their valuable work, and also to Nicholas Rowe from The Written Word.eu for his excellent language revision and commentary on the texts. We are thankful to Margaret Livingston and Silja Kaskinen for their language revision of Saija Kaskinen's article. Last but not least, we are most grateful to the Folklore journal and to the Editor-in-Chief Mare Kõiva for giving us the opportunity to publish this theme issue, and to the copy editor Tiina Mällo and Diana Kahre for the final layout.

The theme number has been initiated and edited within the research project Writing Cultures and Traditions at Borders (SA131578) at the University of Eastern Finland.

\section{NOTE}

1 Ratzel's ideas were misused for extreme nationalistic purposes by the national-socialists in Germany in the 1930s and 1940s (Danielsson 2009). Therefore, some of Ratzel's key concepts and ideas have a notorious reputation; however, this lies outside the scope of this introduction.

\section{REFERENCES}

Aarelaid-Tart, Aili 2006. Cultural Trauma and Life Stories. Helsinki: Kikimora Publications.

Alvarez, Robert R. Jr. 1995. The Mexican-US Border: The Making of an Anthropology of Borderlands. Annual Review of Anthropology, Vol. 24, pp. 447-470, doi: 10.1146/ annurev.an.24.100195.002311.

Anzaldúa, Gloria 1987. La Frontera / Borderlands: The New Mestiza. San Francisco: Aunt Lute Books.

Cahnman, Werner J. 1943. Concepts of Geopolitics. American Sociological Review, Vol. 8, No. 1, pp. 55-59, doi:10.2307/2085449.

Danielsson, Sarah K. 2009. Creating Genocidal Space: Geographers and the Discourse of Annihilation, 1880-1933. Space and Polity, Vol. 13, No. 1, pp. 55-68, doi:10.1080/13562570902780944.

Davydova, Olga 2009. Suomalaisena, venäläisenä ja kolmantena. Etnisyysdiskursseja transnationaalissa tilassa. [Being a Finn, A Russian, or Something In-Between. 
Ethnicity Discourses in Transnational Space.] Joensuun yliopiston humanistisia julkaisuja 57: Joensuun yliopisto.

Douglas, Mary 1966. Purity and Danger. An Analysis of Concepts of Pollution and Taboo. London \& New York: Routledge.

Eskelinen, Heikki \& Liikanen, Ilkka \& Oksa, Jukka 1999. Curtains of Iron and Gold. Reconstructing Borders and Scales of Interaction. Aldershot: Ashgate.

Fingerroos, Outi 2004. Haudatut muistot. Rituaalisen kuoleman merkitykset Kannaksen muistitedossa. Helsinki: SKS.

Van Gennep, Arnold 1909. Les Rites de Passage. Paris: É. Nourry.

Hakamies, Pekka 2012. Karjala venäläisin silmin. Neuvostoasukkaat luovutetussa Karjalassa. [Karelia in the Eyes of the Russians. Soviet Residents in the Annexed Karelia.] In: Outi Fingerroos \& Maunu Häyrynen (eds.) Takaisin Karjalaan. [Returning to Karelia.] Helsinki: SKS, pp. 75-104.

Hammar-Suutari, Sari 2009. Asiakkaana erilaisuus. Kulttuurien välisen viranomaistoiminnan etnografia. [Alien Customer. Ethnography of Intercultural Official Encountering.] Joensuu: University of Joensuu, Publications of Karelian Institute. http://epublications.uef.fi/pub/urn_isbn_978-952-219-303-2/urn_isbn_978952-219-303-2.pdf, last accessed on November 27, 2012.

Häyrynen, Maunu (ed.) 2006. Theme number: Rajoja tilassa ja ajassa. [Theme number: Borders in Space and Time.] Alue ja Ympäristö, No. 2.

Hicks, Emily D. 1991. Border Writing: The Multidimensional Text. Theory and History of Literature Series, Vol. 80. Minneapolis: University of Minnesota Press.

Järviluoma-Mäkelä, Helmi \& Knuuttila, Seppo \& Logrén, Anne \& Turunen, Risto (eds.) 2012. Syrjäseudun idea. Kulttuurianalyysejä Ilomantsista. [The Idea of Remote District. Cultural Analyses of Ilomantsi.] Helsinki: SKS.

Knuuttila, Seppo \& Laaksonen, Pekka \& Piela, Ulla (eds.) 2006. Paikka. Eletty, kuviteltu, kerrottu. [Place: Lived, Imagined, Narrated.] Kalevalaseuran vuosikirja 85. Helsinki: SKS.

Löytty, Olli (ed.) 2005. Rajanylityksiä. Tutkimusreittejä toiseuden tuolle puolen. [Border Crossings. Researching Beyond the Otherness.] Helsinki: Gaudeamus.

Malkki, Liisa 1992. National Geographic: The Rooting of Peoples and the Territorialization of National Identity among Scholars and Refugees. Cultural Anthropology, Vol. 7, No. 1, pp. 24-44, doi:10.1525/can.1992.7.1.02a00030.

Nyman, Jopi (ed.) 2009. Post-National Enquiries: Essays on Ethnic and Racial Border Crossings. Cambridge: Cambridge Scholars Publishing.

Paasi, Anssi 2002. Rajat ja identiteetti globalisoituvassa maailmassa. [Borders and Identity in Globalized World.]. In: Taina Syrjämaa \& Janne Tunturi (eds.) Eletty ja muistettu tila. [Lived and Remembered Space.] Helsinki: SKS, pp. 154-176.

Pöllänen, Pirjo 2007. Etnografinen tutkimus Suomessa asuvien venäläisten maahanmuuttajanaisten perhekäsityksistä. Marginaalissa vai keskiössä? [Ethnography of the Conceptions of Family among Russian Immigrants in Finland.] Lähde. Historiatieteellinen aikakauskirja, pp. 189-201.

Ronkainen, Jussi 2009. Väliviivakansalaiset. Monikansallisuus asemana ja käytäntönä. [Hyphenated Citizens - Multiple Citizenship as Status and Practice.] Joensuu: University of Joensuu. 
Sadowski-Smith, Claudia 2008. Border Fictions. Globalization, Empire, and Writing at the Boundaries of United States. Charlottesville and London: University of Virginia Press.

Schimanski, Johan \& Wolfe, Stephen 2007. Entry Points: An Introduction. In: Johan Schimanski \& Stephen Wolfe (eds.) Border Poetics De-limited. Hannover: Wehrhahn Verlag, pp. 9-26.

Silberman, Marc \& Till, Karen E. \& Ward, Janet (eds.) 2012. Walls, Borders, Boundaries: Spatial and Cultural Practices in Europe. New York \& Oxford: Berghahn Books.

Suutari, Pekka \& Shikalov, Yury (eds.) 2010. Karelia Written and Sung. Representations of Locality in Soviet and Russian Contexts. Helsinki: Kikimora Publications.

Turner, Victor W. 1977. The Ritual Process. Structure and Anti-Structure. Ithaca \& N.Y.: Cornell University Press. 